\title{
Experience of Problem-Based Learning for Raising Quality of Nursing Study
}

\author{
Vida Gönc, Mateja Lorber and Jasmina Nerat \\ Additional information is available at the end of the chapter
}

http://dx.doi.org/10.5772/67427

\begin{abstract}
Introduction: Problem-based learning is a teaching method that encourages critical thinking, group interaction, and application of the theory into practice. Transition to active forms of learning, with integrating problem-solving strategies, will help to raise the quality of education. The aim of the study is to determine students' evaluation of problem-based learning in the study of nursing.
\end{abstract}

Methods: Descriptive method and quantitative research methodology were used. Nursing students from one of the faculties in Slovenia participated in the study and structured questionnaires (Cronbach $\alpha=0.953$ ) were used.

Results: Average values of all items regarding to the student's evaluation of problembased learning were very high ( $>4$ out of 5 ). According to the results, there is no statistically significant difference in the assessment of problem-based learning between full-time and part-time students $(t=-0.818, p=0.414)$, but we found statistically significant differences $(t=2.377, p=0.018)$ depending on whether students are employed in nursing or not.

Discussion and conclusion: Problem-based learning encourages nursing students' motivation, independence, and teamwork and helps to acquire knowledge and skills necessary to function in nursing.

Keywords: problem-based learning, learning, students, nursing

\section{Introduction}

According to the demographic changes of the population, increasing numbers of older people, the rapid changes, and innovations in the field of health care, as well as increasing numbers of people with chronic illnesses, nursing has an increasingly important role [1]. 
Changes in nursing require from nurses, autonomy and the ability to take relevant decisions [2], therefore, is one of the goals of nursing education to reduce the gap between theory and practice $[3,4]$. For an effective transfer of theoretical knowledge into practice, changes are needed. According to Shuler [5], it is necessary to change traditional teaching into the active form of teaching. One of the active ways of learning is problem-based learning. This is an innovative educational method $[6,7]$ which encourages critical thinking and group interaction and represents an advantage compared to traditional ways of teaching, because it integrates problemsolving strategies [8]. Characteristics of problem-based learning are student-centered learning, learning in smaller groups and acquiring new information with self-learning [9]. Problem-based learning improves students' learning and simultaneously helps with problem-solving in everyday life [10]. With the problem-based learning approach, the activity of learning starts with a problem that describes phenomena or events needed for understanding [11]. Simultaneously, the problem-based learning approach activates students' previous knowledge [6].

For a successful problem-based learning after Munshi et al. [12], quality shaped and selected problems are key elements. Research studies $[5,13,14]$ showed that information gained with problem-solving ways of learning is preserved longer. Therefore, in the opinion of authors $[13,15-17]$, learning based on problem-solving develops skills of communication, problemsolving, teamwork, leadership, and understanding; skills that are important for smoother transition into a clinical environment.

The purpose of the study is to determine the evaluation of problem-based learning, and the problems with which nursing students face in problem-based learning.

\subsection{Methods}

A quantitative research method was used. We used a structured questionnaire containing 20 statements regarding students' evaluation of ways of learning based on problems and demographic data (sex, age, type of study, and employment status in nursing). Students' views on the effectiveness of problem-based learning were assessed by using 20 items from the problembased learning evaluation questionnaire [17], which was partially adapted and prepared in Slovenian language. Problem-based learning evaluation questionnaires were already used in studies [17-19]. Using the questionnaire, we evaluated five key dimensions of problem-based learning: construction of professional knowledge, development of problem-solving skills, development of self-directed learning, improvement of motivation, and promotion of effective group collaboration. Each of the studied dimensions contained four items and participants responded on the five-point Likert's scale ranging from (1 - strongly disagree, 2 - disagree, 3 neutral, 4 - agree to 5 - strongly agree). The instrument's internal consistency using Cronbach's alpha was 0.80 and the test-retest reliability with a 2-week interval was 0.89 [17]. The Cronbach's alpha for our questionnaire was 0.953 .

\subsection{Sample description}

The research was carried out among nursing students of the University of Maribor Faculty of Health Sciences. A total of 198 questionnaires were handed out, and 196 were returned which is a $98.9 \%$ response. In the research, 101 (51.5\%) first-year students and 92 (47.0\%) second-year 
students participated, three $(1.5 \%)$ students did not state their year of study. Average age of participants was 21.2 years (ages between 19 and 42). 146 (74.5\%) participants were of fulltime study where $76(38.7 \%)$ were first-year students and $70(35.8 \%)$ were second-year students. Forty-seven (25.5\%) participants were of part-time study where twenty-five were first-year students (12.8 \%) and twenty-two (11.2\%) were second-year students. Three $(1.5 \%)$ students did not write down their type of study. Among the part-time students only 18 students employed in nursing, but other 27 part-time students and all full-time students (146) are not employed in nursing. Two (1\%) part-time students did not write if they are employed in nursing or not.

\subsection{Description of research procedure}

Before we started to execute the research we obtained written agreements from University of Maribor Faculty of Health Sciences leadership and University of Maribor Faculty of Health Sciences Commission for Ethical Questions from the Field of Nursing Care. Based on the agreement the research was carried out in academic year 2013-2014 and academic year 20142015 at course nursing care of women with gynecology and obstetrics and management of hospital infections. At selected course, we started carrying out problem-based learning in 2011.

Participants were informed with purpose and aims of the research. Participation was voluntary and anonymous. Questionnaires were handed out after completing all course obligations of selected courses. Data was processed by the statistical computer program SPSS 20.0. We used descriptive statistics and $t$-test to discover differences between two groups. A $p$-value of $<0.05$ was considered significant.

\section{Results}

Average values of all items regarding to the student's evaluation of problem-based learning were very high ( $>4$ out of 5 ). The lowest average value (4.06) was in item that problem situations encouraged students to continue to study on their own and the highest average values (4.54) were in item that the content of the course is useful for student's future work. Evaluation of problem-based learning dimensions was assessed by students with average value 4.29 (4.26-4.42). The lowest average values received dimensions "development of selfdirected learning" (4.26) and "improving motivation" (4.26). The highest average value received the dimension "promotion of effective group collaboration" (4.42). Table 1 represents results of average values of evaluation of problem-based learning.

With the $t$-test we want to find out if there are any statistically significant differences of evaluation of five dimension of problem-based learning regarding the type of study (fulltime/part-time) and found out that none of the examined dimensions "construction of professional knowledge" $(t=1.194, p=0.234)$, "development of problem-solving skills" $(t=1.010, p=$ $0.314)$, "development of self-directed learning" $(t=0.418, p=0.676)$, "improvement of motivation" ( $t=1.605, p=0.110)$, and "promotion of effective group collaboration" $(t=0.384, p=$ 0.701) not show statistical significant differences (Table 2). 


\begin{tabular}{|c|c|c|c|c|c|c|}
\hline $\begin{array}{l}\text { Items for evaluation of problem-based } \\
\text { learning }\end{array}$ & $\begin{array}{l}1 \text { Strongly } \\
\text { disagree N(\%) }\end{array}$ & $\begin{array}{l}2 \text { Agree } \\
\mathrm{N}(\%)\end{array}$ & $\begin{array}{l}3 \\
\text { Neutral } \\
\text { N(\%) }\end{array}$ & $\begin{array}{l}4 \text { Agree } \\
\mathrm{N}(\%)\end{array}$ & $\begin{array}{l}5 \text { Strongly } \\
\text { agree } \mathrm{N}(\%)\end{array}$ & $\begin{array}{l}\text { Mean } \\
\text { (SD) }\end{array}$ \\
\hline $\begin{array}{l}\text { The course made me use previous relevant } \\
\text { knowledge and experience. }\end{array}$ & $0(0)$ & $3(2)$ & $26(13)$ & $85(44)$ & $81(41)$ & $\begin{array}{l}4.25 \\
(0.742)\end{array}$ \\
\hline $\begin{array}{l}\text { The course helped me to interpret, analyze } \\
\text { and apply key concepts precisely. }\end{array}$ & $0(0)$ & $4(2)$ & $14(7)$ & 103(54) & $74(38)$ & $\begin{array}{l}4.27 \\
(0.682)\end{array}$ \\
\hline $\begin{array}{l}\text { The course furthered my in-depth } \\
\text { understanding of nursing knowledge. }\end{array}$ & $1(1)$ & $0(0)$ & $14(7)$ & $84(43)$ & $96(48)$ & $\begin{array}{l}4.41 \\
(0.670)\end{array}$ \\
\hline $\begin{array}{l}\text { The content of the course is useful for my } \\
\text { future work. }\end{array}$ & $1(1)$ & $1(1)$ & $10(5)$ & $63(32)$ & $119(61)$ & $\begin{array}{l}4.54 \\
(0.668)\end{array}$ \\
\hline Construction of professional knowledge & & & & & & $\begin{array}{l}4.363 \\
(0.561)\end{array}$ \\
\hline $\begin{array}{l}\text { The problem use in the course was challenging } \\
\text { to discuss. }\end{array}$ & $0(0)$ & $6(3)$ & $15(8)$ & $77(39)$ & $97(50)$ & $\begin{array}{l}4.36 \\
(0.756)\end{array}$ \\
\hline $\begin{array}{l}\text { The course increased my ability to solve real- } \\
\text { world problems. }\end{array}$ & $2(1)$ & $4(2)$ & $22(12)$ & $82(42)$ & $84(43)$ & $\begin{array}{l}4.25 \\
(0.813)\end{array}$ \\
\hline $\begin{array}{l}\text { The course encouraged me to consider } \\
\text { alternatives when solving problems. }\end{array}$ & $1(1)$ & $3(2)$ & $24(12)$ & $78(40)$ & $89(45)$ & $\begin{array}{l}4.29 \\
(0.780)\end{array}$ \\
\hline $\begin{array}{l}\text { The course helped me to take reasonable } \\
\text { inferences and conclusions. }\end{array}$ & $2(1)$ & $4(2)$ & 21(11) & $72(37)$ & $96(49)$ & $\begin{array}{l}4.31 \\
(0.825)\end{array}$ \\
\hline Development of problem-solving skills & & & & & & $\begin{array}{l}4.3 \\
(0.690)\end{array}$ \\
\hline $\begin{array}{l}\text { Problem situations encouraged me to continue } \\
\text { to study on my own. }\end{array}$ & $1(1)$ & $9(4)$ & $37(19)$ & $78(40)$ & $70(36)$ & $\begin{array}{l}4.06 \\
(0.883)\end{array}$ \\
\hline $\begin{array}{l}\text { The course helped me to identify gaps in my } \\
\text { knowledge. }\end{array}$ & $1(1)$ & $3(2)$ & $23(12)$ & $80(41)$ & $88(44)$ & $\begin{array}{l}4.29 \\
(0.773)\end{array}$ \\
\hline $\begin{array}{l}\text { The course helped me improve my ability to } \\
\text { identify a variety of resources. }\end{array}$ & $2(1)$ & $5(3)$ & $27(14)$ & $80(41)$ & $81(41)$ & $\begin{array}{l}4.19 \\
(0.745)\end{array}$ \\
\hline The course helped me to think independently. & $0(0)$ & $2(1)$ & $15(8)$ & $62(32)$ & 115(59) & $\begin{array}{l}4.50 \\
(0.686)\end{array}$ \\
\hline Development of self-directed learning & & & & & & $\begin{array}{l}4.26 \\
(0.687)\end{array}$ \\
\hline $\begin{array}{l}\text { The course encouraged me to take an active } \\
\text { role in my learning. }\end{array}$ & $1(1)$ & $6(3)$ & $19(10)$ & $82(42)$ & $87(44)$ & $\begin{array}{l}4.27 \\
(0.801)\end{array}$ \\
\hline The course motivated me to learn more. & $1(1)$ & $8(4)$ & $19(10)$ & $82(42)$ & $85(43)$ & $\begin{array}{l}4.24 \\
(0.830)\end{array}$ \\
\hline The course stimulated my interest in learning. & $3(2)$ & $7(4)$ & $23(12)$ & $80(41)$ & $82(42)$ & $\begin{array}{l}4.18 \\
(0.889)\end{array}$ \\
\hline $\begin{array}{l}\text { The course encouraged my participation } \\
\text { through the discussion of problems. }\end{array}$ & $2(1)$ & $0(0)$ & $20(10)$ & $85(44)$ & $89(45)$ & $\begin{array}{l}4.32 \\
(0.741)\end{array}$ \\
\hline Improvement of motivation & & & & & & $\begin{array}{l}4.26 \\
(0.706)\end{array}$ \\
\hline The course stimulated group discussion. & $2(1)$ & $3(2)$ & $13(6)$ & $64(33)$ & 113(58) & $\begin{array}{l}4.45 \\
(0.774)\end{array}$ \\
\hline $\begin{array}{l}\text { The course promoted open discussion of } \\
\text { differing opinions. }\end{array}$ & $1(2)$ & $2(1)$ & $18(9)$ & $62(31)$ & 111(57) & $\begin{array}{l}4.44 \\
(0.748)\end{array}$ \\
\hline
\end{tabular}




\begin{tabular}{|c|c|c|c|c|c|c|}
\hline $\begin{array}{l}\text { Items for evaluation of problem-based } \\
\text { learning }\end{array}$ & $\begin{array}{l}1 \text { Strongly } \\
\text { disagree } \mathrm{N}(\%)\end{array}$ & $\begin{array}{l}2 \text { Agree } \\
\mathrm{N}(\%)\end{array}$ & $\begin{array}{l}3 \\
\text { Neutral } \\
\mathrm{N}(\%)\end{array}$ & $\begin{array}{l}4 \text { Agree } \\
\mathrm{N}(\%)\end{array}$ & $\begin{array}{l}5 \text { Strongly } \\
\text { agree } \mathrm{N}(\%)\end{array}$ & $\begin{array}{l}\text { Mean } \\
\text { (SD) }\end{array}$ \\
\hline $\begin{array}{l}\text { The course increased my ability to work } \\
\text { effectively on a team. }\end{array}$ & $2(1)$ & $7(4)$ & $20(10)$ & $66(34)$ & $100(51)$ & $\begin{array}{l}4.31 \\
(0.871)\end{array}$ \\
\hline $\begin{array}{l}\text { The course encouraged me to share what I } \\
\text { learned with the entire group. }\end{array}$ & $0(0)$ & $3(2)$ & $15(8)$ & $63(32)$ & $114(58)$ & $\begin{array}{l}4.48 \\
(0.707)\end{array}$ \\
\hline Promotion of effective group collaboration & & & & & & $\begin{array}{l}4.42 \\
(0.651)\end{array}$ \\
\hline
\end{tabular}

Table 1. Results of evaluation of problem-based learning.

\begin{tabular}{|c|c|c|c|c|c|c|c|c|}
\hline & Type of study & Min & Max & Mean & SD & $t$ & $p$ & df \\
\hline \multirow[t]{2}{*}{ Construction of professional knowledge } & Full-time & 1.5 & 5 & 4.34 & 0.587 & 1.194 & 0.234 & 189 \\
\hline & Part-time & 3.25 & 5 & 4.45 & 0.464 & & & \\
\hline \multirow[t]{2}{*}{ Development of problem-solving skills } & Full-time & 1.25 & 5 & 4.27 & 0.704 & 1.010 & 0.314 & 190 \\
\hline & Part-time & 3.0 & 5 & 4.39 & 0.657 & & & \\
\hline \multirow[t]{2}{*}{ Development of self-directed learning } & Full-time & 1.5 & 5 & 4.25 & 0.66 & 0.418 & 0.676 & 188 \\
\hline & Part-time & 2.5 & 5 & 4.29 & 0.738 & & & \\
\hline \multirow[t]{2}{*}{ Improvement of motivation } & Full-time & 1 & 5 & 4.2 & 0.717 & 1.605 & 0.110 & 190 \\
\hline & Part-time & 2.25 & 5 & 4.39 & 0.671 & & & \\
\hline \multirow[t]{2}{*}{ Promotion of effective group collaboration } & Full-time & 2.75 & 5 & 4.43 & 0.629 & 0.384 & 0.701 & 189 \\
\hline & Part-time & 2 & 5 & 4.39 & 0.727 & & & \\
\hline \multirow[t]{2}{*}{ Evaluation of problem-based learning } & Full-time & 1.6 & 5 & 4.3 & 0.574 & 0.818 & 0.414 & 186 \\
\hline & Part-time & 2.85 & 5 & 4.37 & 0.551 & & & \\
\hline
\end{tabular}

Table 2. Results of $t$-test for problem-based learning according to the type of study.

With the $t$-test we also tested statistical significant differences regarding employment or unemployment in nursing and found out there are statistically significant differences of two studied dimensions, "development of problem-solving skills" $(t=2.197, p=0.029)$ and "development of self-directed learning" $(t=4.443, p<0.001)$, whereas at "promotion of effective group collaboration" ( $t=1.699, p=0.091)$, "improvement of motivation" $(t=1.493, p=0.121)$, and "construction of professional knowledge" $(t=2.180, p=0.052)$, we did not find statistical significant differences among students that are employed or not employed in nursing (Table 3 ).

Regarding to the total grade of average values for all five dimensions of problem-based learning from the students' point of view, we found out statistically significant differences regarding employment status (employed or not employed) in nursing $(t=2.377, p=0.018$ ), whereas regarding the type of study, we did not find statistical significant differences $(t=0.818$, $p=0.414)$ at the total grade of average value for problem-based learning. On the open-ended question, students noted next difficulties with problem-based learning: lack of knowledge and information, unequal participation in the group, and the difficulty in finding literature. 


\begin{tabular}{|c|c|c|c|c|c|c|c|c|}
\hline Dimension of problem-based learning & Employ in nursing & Min & Max & Mean & SD & $t$ & $p$ & df \\
\hline \multirow[t]{2}{*}{ Construction of professional knowledge } & Yes & 3.25 & 5 & 4.61 & 0.494 & 2.180 & 0.052 & 190 \\
\hline & No & 1.5 & 5 & 4.34 & 0.564 & & & \\
\hline \multirow[t]{2}{*}{ Development of problem-solving skills } & Yes & 3.75 & 5 & 4.64 & 0.439 & 2.197 & 0.029 & 191 \\
\hline & No & 1.25 & 50 & 4.27 & 0.705 & & & \\
\hline \multirow[t]{2}{*}{ Development of self-directed learning } & Yes & 4 & 5 & 4.68 & 0.381 & 4.443 & $<0.001$ & 189 \\
\hline & No & 1.5 & 5 & 4.21 & 0.688 & & & \\
\hline \multirow[t]{2}{*}{ Improvement of motivation } & Yes & 2.5 & 5 & 4.5 & 0.737 & 1.493 & 0.121 & 191 \\
\hline & No & 1 & 5 & 4.22 & 0.700 & & & \\
\hline \multirow[t]{2}{*}{ Promotion of effective group collaboration } & Yes & 3.5 & 5 & 4.67 & 0.514 & 1.699 & 0.091 & 189 \\
\hline & No & 2 & 5 & 4.39 & 0.662 & & & \\
\hline \multirow[t]{2}{*}{ Evaluation of problem-based learning } & Yes & 3.8 & 5 & 4.62 & 0.394 & 2.377 & 0.018 & 175 \\
\hline & No & 1.6 & 5 & 4.29 & 0.757 & & & \\
\hline
\end{tabular}

Table 3. Results of $t$-test for problem-based learning according to employment in nursing.

\section{Discussion and conclusion}

The research showed that average values regarding all five dimensions of problem-based learning are high. Regarding to the average values, we determined that students recognize the meaning of problem-based-learning approach in effective learning, active cooperation, teamwork, improvement of communication skills, recognition of own learning needs, and transfer of theoretical knowledge into nursing practice, what was also stated as important dimensions of problem-based learning by Yuan et al. [20] and Tseng et al. [21].

Although average values of all dimensions are high, we can agree with Luh et al. [22] regarding to the dimension "construction of professional knowledge" where they state that acquisition of professional knowledge and professional development influences students' previous knowledge and a high degree of thinking ability. On the other hand, problem-based learning helps students to provide professional knowledge and the thinking ability. The importance of previous knowledge and experience also indicates statistically significant difference in the average values of some dimensions of evaluation of problem-based learning, assessed by the students employed in nursing. Despite the fact we have to explain the results with the caution, since in the group of employed students were involved only 18 students. Based on the results, we can conclude that part-time students, who have work experiences in nursing, are more effective at problem solving and with that connected independent learning.

The difficulties of the students, which referred to those students who do not want to cooperate, or unequally cooperate with the group, and the problems of selecting participating students were already pointed by Visschers-Pleijers et al. [23] who stated the importance of selecting a group of appropriate size. Students also identified as a problem, worse understanding of the problem, as already noted by Marentič-Požarnik [24]. We confirmed that students with work experience in nursing are more efficient at problem-solving and independent learning. 
The research indicates the need for problem-based learning with the goal of encouraging independent and active learning and the opportunity for students to make suggestions in the study process. Based on evaluation of teaching methods, higher education teachers can prepare improvement plans. Skinder Savić and Kaučič [25] stated that a quality course and connection of theoretical and practical starting points are key elements for achieving competencies in nursing.

We can finish with the thought that problem-based learning stimulates in students an independent and individual study process, group work, improves work motivation, and communication skills. Problem-based learning stimulates at students the sense for a responsible acquiring of professional knowledge and development of problem-solving skills.

\section{Author details}

Vida Gönc*, Mateja Lorber and Jasmina Nerat

*Address all correspondence to: vida.goenc@um.si

Faculty of Health Sciences, University of Maribor, Maribor, Slovenia

\section{References}

[1] Thiekötter A. Changing tasks for nurses in everyday practice: what type of education and research do we need? In: Skela-Savič B, Kaučič BM, Filej B, editors. Novi trendi v sodobni zdravstveni negi - razvijanje raziskovanja, izobraževanja in multisektorskega partnerskega sodelovanja: zbornik predavanj z recenzijo. 2. mednarodna znanstvena konferenca s področja raziskovanja v zdravstveni negi in zdravstvu; 17-18 September 2009; Ljubljana. Jesenice: Visoka šola za zdravstveno nego; 2009. pp. 114-121.

[2] Billings DM, Halstead JA, editors. Teaching in nursing: a guide for faculty. 3rd ed. St. Louis: Saunders/Elsevier; 2009. 541 p.

[3] Tiwari A, Chan S, Wong E, Wong D, Chui C, Wong A, et al. The effect of problem-based learning on students' approaches to learning in the context of clinical nursing education. Nurse Education Today. 2006;26(5):430-438.

[4] Etheridge SA. Learning to think like a nurse: stories from new nurse graduates. Journal of Continuing Education in Nursing. 2007;38(1):24-30.

[5] Shuler CF. Comparisons in basic science learning outcomes between students in PBL and traditional dental curricula at the same dental school. In: Bridges S, Colman McGrath T, Whitehill L, editors. Problem-based learning in clinical education: the next generation. London: Springer; 2012. pp. 35-46.

[6] Kong LN, Qin B, Zhou YQ, Mou SY, Gao HM. The effectiveness of problem-based learning on development of nursing students' critical thinking: a systematic review and 
meta-analysis. International Journal of Nursing Studies. 2014;51(3):458-469. DOI: 10.1016/j. ijnurstu.2013.06.009

[7] Martyn J, Terwijn R, Kek MY, Huijser H. Exploring the relationships between teaching, approaches to learning and critical thinking in a problem-based learning foundation nursing course. Nurse Education Today. 2014;34(5):829-835. DOI: 10.1016/j.nedt.2013. 04.023

[8] Wang JJ, Lo CH, Ku YL. Problem solving strategies integrated into nursing process to promote clinical problem solving abilities of RN-BSN students. Nurse Education Today. 2004;24(8):589-595.

[9] DeYoung S. Teaching strategies for nurse educators. 2nd ed. New Jersey: Prentice Hall; 2009. 320 p.

[10] Niemer L, Pfendt K, Gers M. Problem-based learning in nursing education: a process for scenario development. Nurse Educator. 2010;35(2):69-73. DOI: 10.1097/NNE.0b013e3181ced891

[11] Wood DF. Problem based learning. British Medical Journal. 2008;336(7651):971. DOI: 10.1136/bmj.326.7384.328

[12] Munshi FM, El Sayed AZE, Dolmans DH. Development and utility of a questionnaire to evaluate the quality of PBL problems. South East Asian Journal of Medical Education. 2008;2(2):32-40.

[13] Chikotas NE. Problem-based learning and clinical practice: the nurse practitioners' perspective. Nurse Education in Practice. 2009;9(6):393-397. DOI: 10.1016/j.nepr.2009.01.010

[14] Cheng CY, Liou SR, Tsai HM, Chang CH. The effects of team-based learning on learning behaviors in the maternal-child nursing course. Nurse Education Today. 2014; 34(1):2530. DOI: 10.1016/j.nedt.2013.03.013

[15] Hung W. Enhancing systems-thinking skills with modeling. British Journal of Educational Technology. 2007;38(1):24-30.

[16] Postholm MB. Group work as a learning situation: a qualitative study in a university classroom. Teachers and Teaching: Theory and Practice. 2008;14(2):143-155.

[17] Yuan HB, Williams BA, Yin L, Liu M, Fang J, Pang D. Nursing students' views on the effectiveness of problem-based learning. Nurse Education Today. 2011;31(6):577-581. DOI: 10.1016/j.nedt.2010.10.009

[18] Al-Kloub MI, Salameg, TN, Froelicher ES. Nursing students' evaluation of problem based learning and the impact of culture on the learning process and outcomes: a pilot project. Nurse Education in Practice. 2014;14(2):142-147. DOI: 10.1016/j.nepr.2013.06.013

[19] Keshk LI, El-Azim SA, Qalawa SA. Quality of problem based learning scenarios at College of nursing in Egypt and KSA: comparative study. American Journal of Education Research. 2016;4(9):701-710. DOI: 10.12691/education-4-9-10 
[20] Yuan H, Williams BA, Fan L. A systematic review of selected evidence on developing nursing students' critical thinking through problem-based learning. Nurse Education Today. 2004;28(6):657-663. DOI: 10.1016/j.nedt.2007.12.006

[21] Tseng HC, Chou FH, Wang HH, Ko HK, Jian SY, Weng WC. The effectiveness of problembased learning and concept mapping among Taiwanese registered nursing students. Nurse Education Today. 2011;31(8):e41-e46. DOI: 10.1016/j.nedt.2010.11.020

[22] Luh SP, Yu MN, Lin YR, Chou MJ, Chou MC, Chen JY. A study on the personal traits and knowledge base of Taiwanese medical students following problem-based learning instructions. Annals Academy of Medicine Singapore. 2007;36(9):743-750.

[23] Visschers-Pleijers AJ, Dolmans DH, Wolfhagen IH, van der Vleuten CP. Development and validation of a questionnaire to identify learning-oriented group interactions in PBL. Medical Teacher. 2005;27(4):375-381.

[24] Marentič-Požarnik B. Problemsko zasnovan študij. In: Mihevc B, Marentič-Požarnik B, Kejžar I, editors. Za boljšo kakovost študija: pogovori o visokošolski didaktiki. Ljubljana: Center za pedagoško izobraževanje Filozofske fakultete, Slovensko društvo za visokošolsko didaktiko; 1998. pp. 123-129.

[25] Skinder Savič K, Kaučič BM. Evalvacija kabinetnih vaj pri predmetu zdravstvena nega otroka in mladostnika s strani študentov Visoke šole za zdravstveno nego Jesenice. Obzornik Zdravstvene Nege. 2010;44(4):231-237. 
